\title{
Uganda's University Library
}

Concentrating primarily upon the library at Makerere University College, the author describes generally the state of the academic library art in East Africa. He points to many contemporary and forwardlooking developments that have occurred in recent years, and he also animadverts upon unfortunate reactionary tendencies. Although all libraries there need increased support, it appears at this time that Makerere is in greatest need of top administrative understanding and concern. Circumstances appear promising, however.

$\mathrm{T}_{\mathrm{H}}$ College is the oldest largest and best reputed institution of higher learning in East Africa. It is, moreover, the bigbrother college of the three constituent colleges making up the University of East Africa, the other two being University College Dar Es Salaam and University College Nairobi. The college is composed of six faculties: arts, science, social sciences, medicine, agriculture, and education. The three last named are designated university faculties. That is, although some basic courses in education, for example, may be taught at Nairobi and Dar Es Salaam, students wishing to take a degree in education are, at least for the present, sent to Makerere from the three East African countries. Likewise, students wishing degrees in law are sent to Dar, whereas those wishing degrees in accountancy or engineering are sent to Nairobi. After 1970, however, it appears that the three constituent colleges will develop into three separate universities with certain coordinating ties. Thus, already Dar and Nairobi are establishing medical schools, and Makerere can be seen to be laying the foundations for faculties of law and

Mr. Sitzman is at the Library, University of Guyama, Guyama, Africa. accountancy. Meanwhile, Uganda Technical College, offering courses on the secondary and junior college levels, is taking steps to upgrade its library to university standards, and some knowledgeable persons forecast its becoming the engineering and technical branch of the future Makerere University. All of these developments and possible developments, of course, suggest implications bearing directly on the Makerere University College library.

In addition to the above-named faculties, Makerere University College is the home of its well known school of fine art, the East African school of librarianship, the Makerere institute of social research (formerly the East African institute of social research), the department of extra-mural and extension studies, and the national institute of education. Altogether, the faculties, schools, and institutes at Makerere provide courses of study leading to fifteen different diplomas and degrees, including the PhD.

Total enrollment for the academic year $1967 / 68$ was near two thousand, including some two hundred postgraduate degree and diploma students. Established posts for teaching staff exceeded two hundred, with another one hundred or so supporting research and technical staff. Staff and students at Makerere carry on vigorous research programs, and students 
and scholars come from all parts of the world to engage in research and participate in its institutes and study programs.

\section{The Libraries}

Serving the complex library clientele described above is a system of three related libraries, consisting of the main library, the Albert Cook library (medical), and the National Institute of Education library, plus the autonomous Institute of Social Research library and numerous autonomous departmental libraries.

The main library. The main library building is a jewel of modern tropical architecture set centrally in a campus noted for its beauty. With floor-to-ceiling windows all round, it is light and airy. An arrangement of individual study tables placed one behind the other in a file next to the windows, with open book and periodical stacks to the inside, creates an atmosphere conducive to study and quiet. Several well-placed lounge areas on each of the three floors contribute to the deceptively relaxed appearance of the building. Altogether, seating in the building can accommodate a total of 382 readers. Facilities for readers do not include carrels. Several "research tables," however, are available for staff and postgraduate students engaged in research. These are tables considerably larger than the individual study tables mentioned previously which may be reserved by individuals for periods of up to two months, the number available being somewhat limited. There is not a great demand for those research tables located in areas open to public access, but the tables in the restricted Africana section usually have a waiting list.

Problems related to the building are mostly administrative and perhaps stem from inadequate planning. For although the building is beautiful and a lovely place in which to work, it is limited functionally. There is considerable wasted space, and the work areas are so ar- ranged that so far it has not been possible to produce an entirely satisfactory and efficient flow of work. The size of most work areas has become inadequate. A great deal of time is wasted in moving materials up and down, and back and forth, instead of in a steady forward flow. No doubt when a new extension is planned the present building will be restudied and many of its present deficiencies remedied.

The original part of the present building was new in 1958. An extension, about one-third of the present structure, was added in 1962. Planned to accommodate about two hundred thousand volumes, the building is again becoming overcrowded. Another extension is anticipated perhaps for 1968. The first extension was linear, and, unfortunately, the new extension will also have to be linear or lateral. Although the present building is strong enough to bear books at any point on its two upper floors, it is not strong enough to be extended upward. Administratively, upward extension would be preferable to linear or lateral extension, and aesthetically it would probably be preferable also. If the new extension should not be forthcoming soon, the librarian will be faced with such choices as to whether to provide more stacks at the expense of the growing demand for seating space or whether to resist the demands for more seating accommodation in order to provide required additional shelving. An alternative which would give only temporary relief would be to move existing shelves closer together. Such a move would sacrifice the comfortable aisles presently enjoyed by readers and library staff alike.

Organization of the main library. In addition to the traditional orders and cataloging sections, the main library consists of a periodicals section, a special collections section, and a bindery and a printing press combined with photographic services. As an organiza- 
tional entity a reference section is conspicuously missing, though a ragtag collection of general reference books does exist. Bibliographies are shelved separately in an area somewhat remote from the general reference books. The loan desk is managed by clerical staff and gets whatever supervision harried professional staff members can spare it.

Refusal of the old-school academics and the central administration to concede the necessity of departmentalization in a modern university library has hindered the work and the desirable development of the library. The attitude which prevails above all others outside the library is that the library does not have catalogers or order librarians-it just has "librarians." The failure to recognize that the library has grown into a complex organization with essential needs for both specialists and generalists on its staff has caused a fine library to deteriorate drastically.

This outmoded attitude at Makerere is particularly difficult to understand in view of the fact that the question of "recognizing" departmentalization of the library has not arisen at other African libraries. Departmentalization is understood to be a sensible method of organization in other institutions of higher learning, and both librarians and administrators and other colleges and universities in the area are surprised to learn that the question has even arisen at Makerere. At Dar Es Salaam the library is equated as a faculty, and the librarian has all the prerogatives of a dean except in salary and in that he does not sit on the council of deans. The deputy librarian is at reader grade. The library system is fully departmentalized, with specialist librarians in charge, and the library is represented regularly on faculty boards. This is in sharp contrast with the situation at Makerere, where the librarian is regularly by-passed in the planning of new courses. He not only does not sit in on the planning of new courses, he is not even asked whether the library has books on a subject or could get them before a new course of study is introduced.

At the University of Zambia the library is equated as a faculty, and the librarian has all the prerogatives of a dean except in salary, which deficiency will likely be remedied soon. The librarian is, ex officio, a member of all boards of study. Although the organizational structure of the library is being deliberately kept fluid for the time being by the university librarian, the librarian has found no obstacles to departmentalization. Moreover, specialist librarians are recruited regularly as required.

Haile Sellassie I University library has in many ways the most enviable status in all of eastern Africa. The librarian has all the prerogatives of a dean, including a seat on the council of deans and heads of administrative units, and commensurate salary. Organizationally, the central library has just been reorganized into two major divisions: The technical services division and the readers' services division. Each division is administered by a specialist librarian with the rank of associate librarian. The technical services division consists of the acquisitions and cataloging departments, each headed by a specialist librarian. The readers' services division incorporates the circulation, documents, periodicals, and reference departments, each in charge of a specialist librarian.

Services. In addition to serving the teaching needs of the college, the Makerere library is called upon to provide materials to serious students and researchers all over Uganda and through its photographic services and interlibrary loans to researchers and scholars throughout East Africa. In the absence of an effective public library service or national library, Makerere library finds itself obligated to assume responsibilities in those directions as well, though the needs of schools are left to the In- 
stitute of Education library. Having the greatest resources and the most comprehensive research collections in all of eastern Africa, it can hardly refuse. Some elements outside the college, however, are dissatisfied with the services available at the Makerere main library and advocate the establishment of a national research library. To follow this line would involve a costly and extravagant duplication of library resources in a small and poor country. This would seem to be particularly so in view of the relative ease with which facilities and services at Makerere could be expanded and developed at a much lower cost. In Zambia the matter of whether the university library will also be recognized as the official national research library has already gone as high as cabinet level in the government, whereas Makerere has not even got around to thinking about the matter.

It is not surprising that persons requiring and wanting good library service should feel resentment toward an institution which maintains a vast storehouse of information yet has never felt the need of developing a reference and information service. In this respect, it is not far wrong to say that Makerere does Uganda and East Africa a disservice, for the prevailing attitude in the college is that old-fashioned notion that an academic library is a building in which library resources are stored and in which students find a quiet place to study their lecture notes. Makerere has yet to discover that a library which fulfills its rightful function is a service organization. This is not to say that there are no academics at Makerere with an appreciation of what a library should be; it is just that their voices, when raised at all, are ignored. One surprising phenomenon is that foundations and other aid organizations have contented themselves with the potentials of service from the Makerere library and have not insisted that the library be adequately equipped as a service organization before pouring great sums of money into the college for teaching and research programs.

It would seem advisable when evaluating teams are sent to universities in developing countries that they include competent librarians to assess library resources.

The collections. The total accessioned book collections of the main library stood at 100,100 volumes in May 1967. The rate of accessions is approximately six thousand volumes a year. The library receives currently some twenty-two hundred and fifty periodical titles, and in the academic year $1966 / 67$ it added more than five thousand separate items to the documents collection. The combined collections of documents and bound volumes of periodicals total perhaps eighty to ninety thousand. The library also has significant holdings of newspapers, microfilms, photographs, manuscripts, and archival materials. Its collection of East Africana is the envy of visiting Africanists. [Further and more precise details regarding the collections may be found in the Librarian's Annual Report for 1966/67.]

Staff and staffing problems. To man the organization thus far described the library had through the years acquired a total of six established posts for professionally trained librarians, despite the fact that the college grew steadily from an institution of sixty teaching staff and 272 students in 1956 to an institution of two hundred teaching staff and nearly two thousand students in 1966 . While the library's collections have grown steadily, the college community has more than quintupled, and demands on the library have increased enormously along with all kinds of development in all of East Africa-the library's established professional posts have remained virtually static for the entire ten-year period.

Working conditions in the library de- 
teriorated to the point that during a period of approximately one year ending in October 1966 the entire professional staff of the main library, some of whom had been with the library for ten or more years, resigned to accept better prospects elsewhere. The lone exception was an Ugandan librarian who had been with the library about two years. Because of the seriously inadequate provision for professional staff in the library, essential work chronically went undone or was done either poorly or incorrectly by inadequately supervised clerical staff.

During the academic year 1966/67 agitation began in the library for adequate staffing in both the main and medical libraries. The typical attitude of the central administration and its old-school academic advisors which the library faced at the beginning of its crusade (and still faces to a somewhat lesser extent) was expressed by one of the highest officers in the central administration who insisted at the beginning that "all that routine work in the library, such as cataloging" can be done by high school graduates. Fortunately, despite considerable opposition from certain academics, the campaign waged by the library resulted in considerable modification of the attitudes held by the central administration and in some of the new posts so urgently required by the library.

The library's campaign resulted in the establishment of two additional professional posts from July 1967, plus one additional post in July 1968. These additions bring the library's established professional posts (including medical) to nine in 1967 and ten in 1968. This compares with twelve established professional posts at Dar Es Salaam in 1967, plus two trainees overseas for professional studies who will be added to the establishment upon their return, bringing established professional posts at Dar to fourteen in 1968. Whereas Makerere ex- pects to have ten established posts in 1970, Dar Es Salaam expects to have about seventeen.

The University of Zambia has established fifteen professional posts for 1967 and expects to establish more as demands on the library increase. Haile Sellassie I University has twelve established professional posts for its libraries in 1967, plus five additional to the establishment. Since it has several sublibraries, this showing of strength in numbers is not quite as impressive as it might appear at first sight.

Recruitment of staff. Recruitment of nonprofessional staff presents little problems. More and better qualified applicants for clerical positions become available all the time. The big problem relative to nonprofessional staff is, as it is in so many other libraries, how to get rid of deadwood. The employees' union at Makerere is so strong that it is virtually impossible to get an undesirable employee dismissed. To be successful, the librarian has to be prepared for a long and gruelling campaign of compiling documentary evidence in the way of written notices of unsatisfactory work sufficient to sustain dismissal charges.

The library, like the rest of the college, has through the years been dependent on expatriates to man its professional posts. Consequently, recruitment problems are more acute. Obviously, selecting staff on the basis of their paper qualifications and on the results of interviews overseas which the librarian has not attended presents difficulties. Oddly enough perhaps the big problem is not a dearth of applicants, despite the scarcity of librarians everywhere. Makerere library continually gets inquiries about work opportunities and unsolicited applications. Probably the biggest hindrance to succesful recruitment is the inefficient, cumbersome, and outmoded recruitment and appointment procedure followed by the college for all academic, professional librarian, and 
senior administrative posts. Even candidates strongly desired by the library or teaching departments and begging to be allowed to work at Makerere finally give up in despair and accept other posts.

Another problem that the library faces is that most of the applicants are inexperienced, whereas under present staffing conditions the library has not been able to take on anybody who does not have enough experience to work with a minimum of supervision. The library establishment, moreover, is too small to permit experimentation in shifting staff about. Ignorance of conditions in Africa in general, and of Uganda and Kampala in particular, very likely prevents some librarians who would most probably enjoy working in Africa from investigating the possibilities. But the working conditions at Makerere for librarians have not been inviting, either. If they were answered honestly, it would take only a very few pointed questions to let an interested librarian know that conditions at Makerere have been extraordinarily difficult.

All this is bound to change for the better, however. Already the climate in the college has warmed considerably toward the library's requirements. New posts have been added to the library's establishment, and it does not now seem to be over optimistic to expect that eventually the library's staffing will be somewhat more commensurate with its needs. Moreover, a very hopeful note is the college's willingness to inaugurate a recruitment program aimed at attracting local college graduates into librarianship by awarding them scholarships for professional training and then by bringing them back to a library with a new atmosphere, one in which they can hold their heads high, proud to be a part of it. The library now has two Ugandan graduates with library qualifications on the staff, and from 1968 it expects to have five.
The medical library. The Albert Cook library, named for a medical missionary to Uganda, is located in the modern Mulago Hospital complex on Mulago Hill, just across a little valley from the main Makerere campus on Makerere Hill. The original part of the library building was new in 1951, and a new extension was completed in 1966. The extension increased the floor space by some 63 per cent. The library now provides seating accommodation for 160 readers and shelf space for approximately fifty thousand volumes. The total accessioned stock, including bound periodicals, stood at about 25,400 in May 1967. The annual rate of accessions over the past four years averaged about sixteen hundred volumes.

Over the past ten years the medical school has increased from thirty-three teaching and research staff in 1956 to 145 in 1966. The medical student body has grown from sixty-two to 324 in the same period. The collection has grown from 12,621 accessioned volumes to over 25,000 in that period, and the number of paid subscriptions for periodicals increased from 171 in 1958 to 290 in 1966. The total number of periodical titles currently received in the medical library exceeds four hundred.

In addition to the staff and students of the medical school the library serves the staff of Mulago Hospital and provides library services, including photocopies of journal articles, to more than one hundred doctors and research workers throughout East Africa. Requests for medical library services from outside the medical school increase every year.

Despite the tremendous demands on the medical librarian, which the above statistics make obvious, the college still has not seen fit to establish more than the one professional post which the library "enjoys." One consequence is that when the medical librarian takes leave ( up to three months' entitlement in alternate years) the medical library remains 
without the services of a professional librarian if staffing conditions in the main library do not permit the sending of a relief librarian. Another consequence is that the medical librarian is continually confronted with the dilemma of choosing which professional duties to defer to the nonprofessional staff. In a way, there really is not much choice, when one considers the understandable reluctance of the medical school staff and other doctors and researchers to accept reference service from clerical staff, who rarely have been above the level of high school graduates. It may be worth bringing out at this point that only in the professional libraries at the medical school and the institute of education have reference and information services been developed to any extent at all at Makerere.

A few years back provision was made for a secretary/assistant to the medical librarian. Sometimes the medical librarian has been fortunate enough to have a college graduate filling the assistant's post. One grave consequence which has arisen from the circumstances described here is that, although the medical librarian has continued to do the classifying, the cataloging has generally been done by the secretary/assistant (more recently called "special assistant). The author catalog and the classified catalog have perhaps suffered little from this arrangement, since LC cards are used and the classifying is done by the medical librarian. But any skilled cataloger who has ever had to edit and revise a subject catalog maintained for many years by catalogers poor in experience does not need a detailed report to understand the deplorable state in which the subject catalog at the medical library finds itself today. $\mathrm{He}$ has only to draw on his own experience to conjure up an accurate picture of all the unwise decisions, wrong choices, and inaccurate representations which have got themselves involved in that catalog.
The medical library has a desperate need for an experienced medical cataloger to edit and revise its subject cata$\log$. Moreover, it is in desperate need of at least a second post for a professionally trained librarian. What is true of the catalogs at the medical library is true of the catalogs in the main library to a lesser extent.

The medical library subcommittee fully supports the medical librarian and has pleaded in vain with the central administration for additional professional staff. It is an unfortunate circumstance for both the medical and the main libraries that those with the most influence in the college with regard to library matters have been academics who do not avail themselves of the library's facilities and who do not see any real value in libraries anyway. And it is of considerable significance that the chairman of the parent library committee may be numbered among that group.

The institute of education library. Until 1965 the institute of education library was completely autonomous from the college librarian. In that year and through the efforts of the college librarian it was "brought into a relationship with the main library similar to that of the Albert Cook library. Owing to the different constitution and financial support of the institute the connection is not identical, but a library committee with members from the institute and the college, including the librarian, has been formed to decide policy matters and a subcommittee to consider book and periodical purchases." [cf. the Librarian's Annual Report 1965/66.]

The library serves the faculty of education and its $\mathrm{BEd}$ and postgraduate DipEd students, as wells as the institute of education, which conducts a oneyear upgrading course for tutors in Uganda teacher training colleges. It also extends borrowing privileges to the staffs of training colleges and schools throughout Uganda. Altogether the institute of 
of education library catered to slightly more than four hundred registered borrowers at the end of the academic year 1966/67. As facilities increase and services can be expanded, the demand will, of course, become greater.

The library has been manned by one professional librarian, who performs all professional duties in that library, including ordering and cataloging. It is expected, however, that an additional professional post may be added in the near future. The total stock includes over twenty thousand books, of which some seven thousand constitute a textbook collection. Acquisitions of books, substantial pamphlets, and textbooks for the year 1966/67 totaled more than twentyfive hundred. The library receives currently some eighty periodical titles. Total loans for the year were in the vicinity of fifty-six hundred. The education librarian puts out a bulletin/accessions list called "Notes and News." About twenty issues appeared during the year 1966/67.

Administratively, the institute of education library ought to be completely under the college librarian, preferably as a service unit only, with its ordering and cataloging done in the respective departments of the main library, as it is done in other universities in eastern Africa. The divided responsibility for finances should not present insuperable obstacles, and the benefits to be derived from the points of view of both economy and service recommend such realignment and reorganization.

The Institute of Social Research Libra$r y$. The institute of social research library is a small working library of some three thousand books, plus a substantial collection of dissertations, conference papers, and unpublished manuscripts oriented to the needs of one of the most vigorous research programs of the college. About one hundred and fifty readers use the library regularly. It apparently has never been in charge of a pro- fessionally trained librarian nor of anyone who has worked full time. The ties between the institute and main library seem never to have been adequately and clearly defined. It appears that the college librarian at one time exercised some degree of administrative control over the institute library but that somehow this influence got lost along the way. From all points of view it would be highly desirable that the institute of social research library be incorporated into the main library at least administratively if not physically.

Other autonomous departmental libraries. It is a regrettable policy which permits college funds to be used to hire unqualified persons to serve as librarians without any responsibility whatever to the college librarian and to squander college money on the establishment of wasteful and unnecessary duplicate collections on campus.

There is no justification for departmental libraries over which the college librarian is allowed to exercise neither influence nor control. If the college actually needs departmental libraries, and opinion is divided as to whether it does, they would more properly be planned in cooperation with the college librarian and placed under his administration. The present practice results in wasteful expenditure of college funds through unnecessary duplication and in undermining the main library.

Ostensibly, funds are allocated to the departments for the purchase of reference materials which are required so frequently that purchase for retention in the department is justified. The heads of some departments, however, go far beyond this intention and set themselves up in competition with the legitimate library service of the college. One such library is that of the department of mathematics, a library of some three thousand titles. Through the years the department, one of the smallest in the college, has acquired unto itself one of 
the largest allocations of college funds for the purchase of so-called reference books and periodicals. Why, one may well ask, does the department of mathematics require $£ 200$ per annum for books and periodicals ostensibly for office use, whereas the department of surgery requires only $£ 20$, and fine art, political science, and religious studies $£ 40$ each?

The obvious answer seems to be that in the case of mathematics the professor has set himself up as a rival to the college librarian. He has managed for himself a departmental book allocation larger than the allocation from the main library's book funds for mathematics. Thus the mathematics department library is growing at a greater rate than the mathematics section of the main library's holdings. Moreover, the mathematics department library is a circulating library to students, though no account of this has apparently ever been made to the college librarian. It would seem to be a possible conclusion that the professor of mathematics $\mathrm{cum}$ chairman of the library committee has been empire building at the expense of the main library.

The case cited here is not the only one which could bear some investigation to the college's benefit. Considering certain factors, however, it seemed to be the one most worthy of pointing out.

In the matter of autonomous departmental libraries, Makerere could well learn from the younger universities at Dar Es Salaam, Lusaka, and Addis Ababa. In all of these institutions it has been recognized that autonomous departmental libraries can be wasteful and cancerous growths, and steps have been or are being taken to eradicate them. University of Zambia library makes permanent loans to departments, but the books remain the property of the central library. Haile Sellassie I University goes even further in defining the prerogatives of its central library and li- brarian and in protecting the interests of its library. Everything is set forth clearly and unequivocally in the university's "Statute on the Library" of 1965, a document which merits careful study by any university or college authorities wishing to reappraise the status of their own library.

Whereas other universities in the area have taken firm measures against autonomous departmental libraries, Makerere has buried efforts to put its librarian in charge of all library materials in committees. [cf. The Librarian's Paper on Departmental Collections, LC/65/1; Library Committee Minutes Nos. 1/652/65; Academic Board Minute 2404 (Library Committee Minutes) of its 179th meeting on 24 March 1965.]

The library committee. The composition of the library committee at Makerere is similar to that at University College Dar Es Salaam and University of Zambia, with, however, certain significant differences. Whereas at Makerere the deputy librarian is officially present only as a nonvoting observer, at both Dar Es Salaam and Zambia the deputy librarian is, ex officio, a voting member of the committee. At Zambia the deputy librarian is also, ex officio, the secretary of the committee. This arrangement is especially good in that it relieves the librarian of the responsibility of taking notes and leaves him free to concentrate on the main business of the meeting. In contrast to the situation at Makerere where the librarian sits on academic board without friends, so to speak, the chairman of the library committee at Dar Es Salaam takes the library committee minutes in academic board and presses the library's interests, with the librarian sitting as his advisor. This, of course, requires a chairman who is fundamentally concerned about the quality of the university library and the service it renders as well as one who is both informed and willing to be informed on modern library practice. 
The situation at the University of Zambia is even better, in that the vice chancellor is not only genuinely interested in the library and regularly avails himself of its facilities but he also chairs the library committee and takes an active interest in library affairs. This contrasts sharply with the situation at Makerere, where the principal apparently has never even attended a library committee meeting and only sets foot in the library when some important official, such as an ambassador, requests him to accept a gift to the library in the library. In fact, one of the serious shortcomings at Makerere is that neither the principal, the former vice principal, the secretary/registrar, nor the chairman of the library committee use the main library so they have no idea of what goes on inside a modern library.

At Haile Sellassie I University the library committee is "a standing committee consisting of one representative of each Faculty, School, College, and Institute of the University, the Librarian and, ex officio, of the Academic and Business Vice Presidents." [cf. its Statute on the Library.] Thus from the point of view of its library committee the library at Haile Sellassie I University is also on a par with the faculties.

A view to the future. There seems to be little reason to doubt that conditions in the libraries and library service at Makerere University College will continue to improve if leadership in the library remains vigorous. There is, however, uncertainty as to whether Makerere library will retain its imminence. Until recently Makerere library has been the most eminent library in eastern Africa and second only to Ibadan University library in all of Black Africa. In recent years the three new university libraries discussed above have arisen in eastern Africa to present a strong challenge to Makerere's leadership in library service and development. In fact, about the only university library in eastern Africa which does not present any challenge to Makerere, with the possible exception of the University of Malawi library, is University College Nairobi library.

The University College Dar Es Salaam library, though much younger than the Makerere library and presently serving a college about one-third the size of Makerere University College, has been much better provided for in the way of permanently established posts at all levels. In 1967, for instance, whereas Makerere has provisions for nine professional librarians for both the main and medical libraries, Dar Es Salaam will have twelve. Dar Es Salaam as yet has no medical library, but when one is established, it will have an establishment additional to that of the main library. It is not surprising, then, to observe that library service is much more advanced in many ways at University College Dar Es Salaam than at Makerere. Nor is it surprising that the complaint should arise that the development of library services at Dar Es Salaam is held back by Makerere's backwardness in library affairs. Since the university grants committee passes on the budgets and sets the total expenditure on all three of the constituent colleges of the University of East Africa, these discrepancies are noted, though not always correctly interpreted.

The University of Zambia library, like the University College Dar Es Salaam library, is fortunate not only in having the keen and active support of the university as a whole but also in having in the country a soundly established public library service with competent and vigorous leadership.

In fact, a librarian's visit to Dar Es Salaam and Lusaka turns out to be an exciting and stimulating adventure. At the two universities themselves the existing library building at Dar and the proposed building at Zambia, planned

(Continued on page 212) 
being developed in the medical sciences. Finally, methods for supporting teaching and research at a growing number of coastal marine research institutes and stations, often hundreds of miles from the parent institution, either through collection duplication or rapid transmission of information, must be developed. While on-site research is not unique to marine science, it is, by the very nature of the subject, characteristic of it.

The National Sea Grant College and
Program Act of 1966 is significant legislation which will probably alter the direction of curriculum development and research in many institutions of higher learning. The extent to which this is true is, of course, dependent upon the continuation of the current trend for the federal government to support development of marine resources. All indications seem to be that this trend will both continue and increase.

\section{UGANDA}

(Continued from page 209)

as university library buildings from the start, are a far cry from the inadequately planned development of the physical plant at Makerere, which remains nothing more than a small residential college library. Moreover, one cannot help contrasting the enthusiasm and high morale in these two libraries with the cloud which has hung over the Makerere library during the last year or two.

If one accepts as fundamentally sound the following statement made by the university grants committee in England as far back as 1924, he can make his own deductions accordingly from the information adduced herein. Commenting on the condition of university libraries in England, the committee expressed itself thus: "The character and efficiency of a University may be gauged by its treatment of its central organ-the Library. We regard the fullest provision for library maintenance as the primary and most vital need in the equipment of a University. An adequate Library is not only the basis of all teaching and study; it is the essential condition of research, without which additions cannot be made to the sum of human knowledge." It seems hardly worth pointing out that the University Grants Committee was not composed of librarians.

However one looks at it, the future of Makerere University College is integrally tied to what it does with its library. In this respect, it would hardly seem unfair to conclude that the Big Brother of universities in eastern Africa has become a doddering reactionary, sitting at a fork in the road, looking backward over the way he has come and muttering foolishly about his own supposed greatness, while his more vigorous and progressive younger brothers overtake and stream past him up both forks of the road. 